\title{
Hungary starts to tackle pollution
}

Hungary has recently set up a new National Council for the Environment and Nature Protection. The council has the status of a State Committee under the Council of Ministers, and a membership which includes those ministers and heads of national bodies concerned with environmental protection, and scientists and specialists.

Environmental protection has been a long-standing matter of national concern in Hungary - and the history of governmental counter-measures is almost equally long. On formal and prestige occasions, it is even possible for orators and publicists to hark back to the days of the Dual Monarchy and cite the Public Health Act of 1876, which inter alia empowers the authorities to "use compulsions to remove everything which pollutes the air, the soil or the waters . . . and to establish anything which promotes public health".

Unfortunately, of recent years, concern has not always been matched by action. The new law on the protection of the human environment, which was presented to the National Assembly in 1974, was not in fact passed until March 1976. (Press releases at the time of passage of the Bill hinted that the delay was due to incorporating the recommendations of the Helsinki Final Act into the final format.)

Similarly, although a National Antipollution Committee was set up in 1969, the definition of its terms of reference proved a very slow process, and almost a year later the newspaper Nepszava pointed out that no ruling had yet been given as to the committee's authority on the national level. Not surprisingly, law-suits on questions of pollution were not uncommon: sometimes, indeed these verge on the Gilbertian, as in the 1972 action against the Borsod Cement and Lime Works. The dust emitted by the Hejocsaba unit of the works was emitting pollutant dust which was alleged to affect the quality of fodder, the composition of the soil, damage the fish hatcheries and even affect pollination. The case turned on the precise legal definition of "activity fraught with excessive danger". (An equally ludicrous situation arose in 1977, when, although the Debrecen Synthetics Plant was emitting 4-5 times the maximum permitted level of lead, the plant went on operating, since no one seemed sure who should be responsible for closing it down!)

Equally ironic is the case of the Lake Balaton Area. The Little Balaton, once a part of the main lake, is now connected to it only by the river Zala and is largely reed-grown, providing an excellent habitat for such rare species as the little egret (Egretta garzetta), the bittern (Botaurus stellaris), spoonbill (Platalea), and some of the last tufted herons (Egretta alba) in Europe. Yet Lake Balaton proper, until the early 1970s, was itself a 'reservation'for foreign motor boats, which by then had been banned from almost all the lakes of Europe. Apart from the pollution hazard to the lake itself, the noise and atmospheric pollution from the boats caused considerable outcry in the media, which urged the banning of the offending vessels.

During the 1970 s a number of practical measures were introduced. A system of progressively increasing fines were imposed on industrial enterprises which contravened air pollution regulations - the proceeds going to antipollution $R$ and $D$ and to the installation of anti-pollution equipment.

The maximum sulphur content of domestic solid fuels in central Budapest was restricted to a maximum of $1 \%-$ thus creating one of the few 'smokeless zones' in Eastern Europe. The Patriotic People's Front -an umbrella organisation for political mobilisation-was drawn into the programme. One of its first suggestions - at the Visegrad Conference of 1973, was that courses in environmental protection should be included in curricula at all levels of education.

By the time the Environmental Protection Act was finally passed in 1976, Dr Karoly Garamvolgyi, Deputy Minister of Education, could inform the press that "instruction is given in environment protection and antipollution measures on every level of education from the kindergarten and first-level education through secondary schools and skilled workers' training schools, to the third-level in our colleges and universities, and finally in postgraduate training." Nevertheless, he thought that more could be done for the 3 to 6 age group. The teachers' training colleges, he said, were still not putting sufficient emphasis on these problems; however, a new primary school syllabus had recently been worked out, "in which the subject is treated in integration with other subjects".

In spite of all efforts, the situation, as reported by the Hungarian radio last June, is still far from satisfactory. The annual damage from pollution equals 2.5 to $3.0 \%$ of the 'national income' (a Marxian term roughly equivalent to the net material product, but with certain 'non-productive' factors
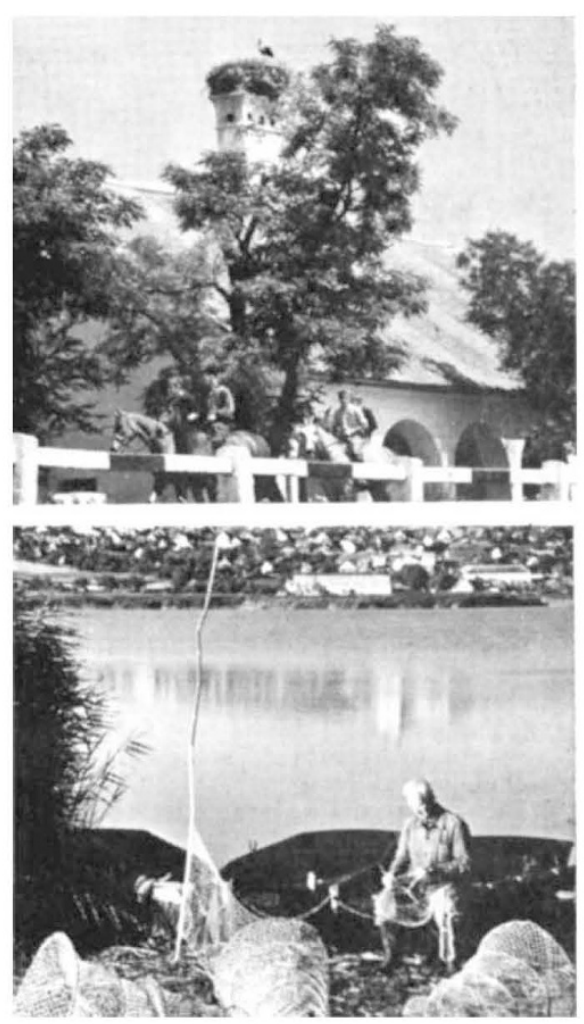

All clear at Hortobagy and Lake Balaton but industrial pollution is the main problem

omitted). Some 14,500 ha of land are lost to agriculture each year, largely due to the spread of industry and mining. Some 50 to 150 tonnes of solid industrial waste (fly ash, heavy metal dust, slag, etc) pollute every sq $\mathrm{km}$ of soil per year.

Logistic factors and lack of resources undoubtedly play a part here. Thus in 1971, when there were a number of problems as to the best means of purifying industrial wastes, an experimental programme was introduced at Kecskemet, using unpurified industrial wastes to irrigate crops.

Nor is Hungary's record entirely gloomy. In 1973, the Swiss-based Goethe Foundation awarded the Europa prize to Laszlo Madas, Director of the Pilis Forest, for his 'outstanding services' to ecology.

This award, perhaps, is significant; to date Hungary's major successes have been in the establishment of nature reserves and protection areas, rather than in the combatting of industrial pollution. The establishment of a new breeding centre for bustards, the setting up of the National Park of Hortobagy, with its aboriginal grey cattle, or the protection of the creeping sand-hills of Kiskunsag-all this appears to come far more easily to the Hungarian planners than the combatting of industrial pollution. It is to be hoped that the new Council, with its co-ordinating powers, will be able to deal with this far more insidious problem.

Vera Rich 